Greece Ev Rome, Vol. 53, No. 2, (C) The Classical Association, 2006. All rights reserved doi: 10.1017/S0017383506000283

\title{
GREEKS, BARBARIANS AND AESCHYLUS' SUPPLIANTS
}

\author{
By LYNETTE G. MITCHELL
}

Ten years after producing the Persians in $472 \mathrm{BC}$, in which Greeks and barbarians are locked in conflict with each other, Aeschylus in the Suppliants explores the inextricable intertwining of Greekness and barbarity. While even in the Persians Aeschylus recognizes the ultimate 'kinship' between Greek and barbarian (the women of Atossa's dream - one wearing Persian robes, the other Dorian - are described as 'sisters of one race': Aesch. Pers. 180-7), ${ }^{1}$ in the Suppliants the poet develops this theme and casts it in sharper relief. In this later play, now generally accepted (despite archaic or archaizing elements) to have been produced in the late $460 \mathrm{~s},{ }^{2}$ Aeschylus is more actively interested in the ways in which kinship both intersects with and is complicated by cultural polarity, and at the same time undercuts and complicates 'Otherness'.

Although it is often said that the Persians was the only play with a cast wholly from Asia, all the cast of the Suppliants except Pelasgus the Argive king were also from Asia, and explicitly so. Further, as in the Persians, the Greek/barbarian polarity underpins the characterization of the Danaids and their cousins the Aegyptiads. But the Suppliants locates this difference within the framework of kinship between Danaids, Argives, and Aegyptiads (not just the 'dreamed' - and

1 The fact that Aeschylus connects Europe/Greece and Asia in this way is rarely given much weight by commentators: see esp. L. G. Mitchell, Panhellenism and the Barbarian in Archaic and Classical Greece (Swansea, forthcoming). Both Suzanne Saïd, 'Greeks and barbarians in Euripides' tragedies: the end of differences? (transl. A. Nevill)', in T. Harrison (ed.), Greeks and Barbarians (Edinburgh, 2002), 62-100; originally published as 'Grecs and Barbares dans les Tragedies d'Euripide: le Fin des Differences?', Ktema 9 (1984), 27-53, and Edith Hall, Inventing the Barbarian (Oxford, 1989) argue that real change in the representation of Greeks and barbarians in Athenian tragedy only comes with Euripides at the end of the century.

2 For the date, see esp. A. F. Garvie, Aeschylus' Supplices: Play and Trilogy (Cambridge, 1969), 1-162, who opts for a date 'in the late 460s'. O. Taplin, The Stagecraft of Aeschylus. The Dramatic Use of Exits and Entrances in Greek Tragedy (Oxford, 1977), 194-8, settles for the range 466-59 вс. H. Friis Johansen and E. W. Whittle, Aeschylus. The Suppliants, 3 vols (Copenhagen, 1980), 1.22-3, tentatively suggest 463 but note that 'other years within the decade 466-56 (excepting 458, the year of the Oresteia) cannot be excluded.' Cf. A. Sommerstein, Aeschylean Tragedy (Bari, 1996), 152-8. S. Scullion, 'Tragic Dates', $C Q^{2} 52$ (2002), 87-101, however, now wants to re-date the Suppliants because of doubts about the papyrus that dates the play to the 460 s. Scullion suggests on stylistic grounds that 'a date of $c .475$ would suit it very well'. 
distancing - kinship of the Persians), so that the daughters of Danaus are both 'insiders' and 'outsiders'. The juxtaposition of the physical appearance of these figures with their Greek ancestry is striking (given immediacy through the presence of Pelasgus) and ultimately shocking. As a consequence, this play is interesting as an indication not only of the ways in which attitudes to the barbarian world were being confronted, contested, and changed in the mid fifth century, but also for the fact that, so soon after Xerxes' invasion, they could be so again, in a manner reminiscent of the late sixth century. ${ }^{3}$

Aeschylus' willingness (or ability) to explore such issues seems to coincide with more tolerant political conditions. By the late 460 s the political relationship between Greeks and barbarians had also eased. In response to the Persian invasions at the beginning of the fifth century, the Greeks, celebrating their victory as one common to Hellas ([Simonides], XV Page $F G E$ ) and as deliverance from hateful slavery (Diod. 11.33.2 = [Simonides], XVII (b) Page FGE), determined by means of the Delian League to carry a retributive war into Asia. By the 460s, however, the initial fervour of war against the barbarian having passed, the Athenians were becoming a formidable force in the Aegean, and were probably moving towards regarding the Delian League as the basis of empire. ${ }^{4}$ By the late 460 s relations between the Athenians and Spartans were also in crisis, and the alliance against Persia was broken off (Thuc. 1.102). There were also the beginnings of trouble (which Athens turned to her advantage) in the Delian League, and the realities posed by competition for power among the Greek states, and especially Athens and Sparta, were becoming more important than the Persian threat.

In this article, I will explore the ways in which Aeschylus in the Suppliants develops a complex understanding of the relationship between Greeks and barbarians, and how this revision not only reflects the political situation in the mid fifth century, but also helps to open the way for a new political relationship for the Athenians and the Persian empire. We will begin by looking at the problems surrounding the tetralogy to which the play belongs, since the Suppliants and its significance can only be fully appreciated and understood in that context. Next we will turn to the play itself and consider the

\footnotetext{
3 The cultural relativism of Herodotus and Antiphon (esp. 44 fr. B, col 2) finds its roots in the sixth century, and especially Xenophanes of Colophon (DK 2 B 16). On differences between the relativism of Herodotus and Antiphon: R. Thomas, Herodotus in Context. Ethnography, Science and the Art of Persuasion (Cambridge, 2000), 132-3.

4 This is made clear at least by the moving of the treasury of the League to Athens in $454 \mathrm{BC}$ (cf. $I G \mathrm{i}^{3} 259$ ), even if the dating of the inscriptions relating to empire is less than secure.
} 
nexus of relationship between the Danaids, the Argives and the Aegyptiads, which made all kin despite cultural differences, and the social and cultural implications of these relationships. Finally, we will return to the political context in which the play was produced and the implications for political relations between Athens and the non-Greek world of the production of this play (and tetralogy) at the Great Dionysia in the 460 s.

\section{The Suppliants and the Tetralogy}

Before we can think about the Suppliants itself, we need to come to some understanding of its role within the tetralogy. Aeschylus' Suppliants was one of a sequence of four plays which almost certainly also included Aegyptians, Danaides, and the satyr play Amymone, and which were all almost certainly concerned with the story of the daughters of Danaus. ${ }^{5}$ The myth from which the plot of the trilogy is drawn, the story of Io, probably dates in this form to the early sixth century, and forms part of the mid sixth-century (now fragmentary) Catalogue of Women. ${ }^{6}$ The story, as agreed by most sources, is that Io was the priestess of Argive Hera, that Zeus fell in love with her, and that she was turned into a cow because of Hera's jealousy either by Zeus

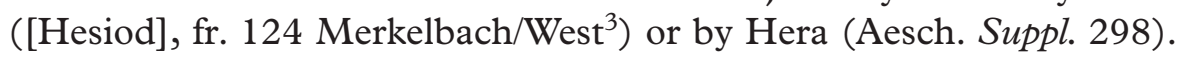
Stung by a gad-fly sent by Hera, the cow-shaped Io wandered from Greece to Asia and finally to Egypt where she gave birth to Epaphus beside the Nile. Epaphus' daughter, Libye, then gave birth to Belus, who was in turn the father of two sons, Aegyptus and Danaus. Aegyptus had fifty sons and Danaus had fifty daughters.

5 The papyrus fragment which suggests the date (or at least the date range), POxy.2256.3, connects Danaides and Amymone. Strabo (5.2.4) seems to think that Suppliants and Danaides go together, and an apparent confusion in the Etymologicum Gudianum (p. 578.10-12) between Aegyptians and Suppliants (cf. Suppl. 156-8) seems to suggest that they also belong in the same sequence (see Garvie [n. 2], 13-14, 188-9; Friis Johansen \& Whittle, [n. 2], 1.23-4), although note the reservations of Taplin (n. 2), 195-6, who suggests the possibility, on the basis that not all tetralogies comprise plays in a connected sequence, that the four plays do not belong together in the same tetralogy, or that they do not belong together in the same year.

6 The 'Asiatic digression' almost certainly dates to the period after the Greeks first settled in Egypt, that is the mid seventh century; see M. L. West, The Hesiodic Catalogue of Women (Oxford, 1985), 149, 154. Argos' acquisition of the Argive Heraeum, which seems to date to the late seventh/early sixth century - I. Strøm, 'The Early Sanctuary of the Argive Heraion and its External Relations (8th - early 6th cent. B.C.)', Proceedings of the Danish Institute at Athens 2 (1998), 37-125; J. Hall, Ethnic Identity in Greek Antiquity (Cambridge, 1997), 89-107 - appears to provide a terminus post quem for the form of myth which links to myth specifically to Argos; $\mathrm{cf}$. L. G. Mitchell, 'Euboean Io', $C Q^{2} 51$ (2001), 239-52. 
The trilogy, comprising Aegyptians, Suppliants, and Danaides, though not necessarily in that order, probably concerned at least the flight of the daughters of Danaus to Argos to escape marriage with their cousins, the fifty sons of Aegyptus (the plot of the Suppliants), the marriage of the cousins, the murder of the sons of Aegyptus by the daughters of Danaus, and the disobedience of one of the daughters, Hypermestra, who saved her husband Lynceus, since these three elements form part of almost all versions of the myth. ${ }^{7}$ External sources provide evidence of some narrative elements which may have formed part of the trilogy. Pindar says that Danaus conducted a competition to find husbands for his forty unmarried daughters (Pyth. 9.111-16; cf. [Apoll.] 2.1.5 who refers to the competition; Hyg. Fab.1 70.1 who has the daughters marry Argives), and there are allusions in the Suppliants to the fact that the Danaids will marry either the Aegyptiads or Argives (esp. Aesch. Suppl. 1054-5). ${ }^{8}$ There are perhaps also oblique allusions within the play to the Danaids' murder of their cousins (e.g. Aesch. Suppl. 6. 449), an element which is also picked out by the Prometheus Bound (860-6), along with Hypermestra's disobedience, here attributed to himeros, 'yearning desire'. Further than this it is difficult to go with firmness, particularly as there was more than one version of the myth available to Aeschylus to choose from. Fragments of the Hesiodic Catalogue of Women give a version in which the sons of Aegyptus went to Argos without their father (fr. 127 Merkelbach/West ${ }^{3}$ ); Phrynichus used or invented in his play the Aegyptii a variant in which Aegyptus accompanied his sons to Argos (schol. Eur. Or. 872). ${ }^{9}$

The problem is compounded by uncertainty over the order of the plays. We know the order of the last two plays, Danaides and Amymone (P Oxy. 2256.3). There is little doubt that the Amymone is the satyr play, making Danaides the final play of the trilogy, but there is no external evidence for the order of the first two plays. It is generally assumed that Suppliants is the first of the trilogy on the basis both that the Suppliants adequately introduces the action of the whole narrative and that it would be difficult to fit the rest of the plot into only one

7 See Garvie (n. 2), 164. 226.

8 See esp. R. A. S. Seaford, 'The Tragic Wedding', $7 H S 107$ (1987), 116-17; Garvie (n. 2),

9 Another fragment (fr. 128) refers to the fact that the Danaids made Argos 'well-watered', though it had previously been waterless, which may reflect in some way the story given by [Apollodorus] (2.1.4) - probably also the subject of Aeschylus' satyr play - of Amymone, who in her search for water, threw a dart at a deer but hit a sleeping satyr. Poseidon then rescued her from the satyr, slept with her himself, and showed her the springs of Lerna. 
play. Nevertheless there are objections to this reconstruction, since if the second play is concerned with the murder of the Aegyptiads, it would be strange to kill or plan to kill the chorus since the play must be named after the sons of Aegyptus or their servants. ${ }^{10}$ However, if Aegyptians is the first play, it is unclear what narrative it would have included. Although it could conceivably provide the reasons for the girls' flight, there is no apparent reference in Suppliants to a quarrel between Danaus and Aegyptus, which is included in other versions ([Apoll.] 2.1.4; schol. Prom. 853a; schol. Il. 1.42; Hyg. Fab. 168.1), and which might explain the flight of the maidens, and it is usually assumed that this did not form part of Aeschylus' story. ${ }^{11} \mathrm{~A}$ fragment of an epic poem Danais, which is almost certainly older than Aeschylus, refers to the daughters of Danaus fighting by the banks of the Nile (fr. 1 Davies $E G F$ ), but as Friis Johansen and Whittle note, this would apparently entail a change of character for the Danaids (who are not willing to fight the Aegytiads for themselves, which is why they supplicate the Argives) if it were to form part of the trilogy. ${ }^{12}$ Allusions within the Suppliants, on the other hand, suggest that war will follow (e.g., Aesch. Suppl. 341-3, 410-13, 439-40, 474-7, 740, 934-7, 950). This may form the plot of the next play, if the next play is Aegyptians, or fall between the Suppliants and the next play, which would ease the quantity of narrative which the trilogy needs to cover.

Whatever the difficulties in reconstructing the trilogy, it is generally agreed that the major theme of the trilogy, like that of the Suppliants, is marriage, whether it is marriage in general which is at stake, marriage to the sons of Aegyptus themselves, or an endogamous marriage to cousins. ${ }^{13}$ Not only is the action of the Suppliants itself

10 On the sequencing of the Aegyptians and the Suppliants: Garvie (n. 2), 185-6, 196; Taplin (n. 2), 195; cf. Sommerstein (n. 2), 143-6.

${ }_{11}$ Garvie (n. 2), 171; Friis Johansen \& Whittle (n. 2), 1.33.

12 Friis Johansen and Whittle (n. 2), 1.44. Sommerstein, (n. 2), 144-51, suggests a different reading of the trilogy, based on evidence which he claims confirms late references to an oracle warning Danaus that he would be killed at the hand of the sons of Aegyptus in general, or Lynceus in particular (see schol. Eur. Or. 872, schol. Prom. 853a, schol. Il. 1.42). For Sommerstein, this event (death at the hands of Lynceus), known only from very late sources ([Archil.] ap. Malalas p. 68.1 D; Serv. Dan. 10.497; cf. Hyg. Fab. 170.11; but note Friis Johansen \& Whittle's reservations: [n. 2], 1.49), is the climactic event of the trilogy.

${ }_{13}$ R. P. Winnington-Ingram, 'The Danaid Trilogy of Aeschylus', fHS 61 (1961), 141-52, at 150: 'Many issues have been raised: issues of religion and politics and society and individual decision, inextricably interwoven (as they always are in Aeschylus). The central thread is that of men, women and marriage.'; Garvie (n. 2), 204-33, at 205: ' $\ldots$ a trilogy that is concerned with marriage and its consequences.'. Friis Johansen \& Whittle agree that 'in the end Eros must somehow have been victorious', (n. 2), 1.42, but suggest that the Suppliants 'undoubtedly raises in a powerful, if incomplete, way the problem of arranged marriage' (1.40). Seaford (n. 8), in a sophisticated study of the negative tendency (here the negative aspects of endogamy) in marriage ritual, revives an old view that the play ended with the institution of the Thesmophoria, replying 
created by the Danaids' aversion to marriage with the sons of Aegyptus, but also two fragments which can confidently be assigned to the final play in the trilogy seem to suggest that the theme of marriage is carried right through the trilogy. The first (fr. 43) is corrupt, although it seems to be part of a bridal waking-song, which it has been suggested may have been sung either after the Danaids' fateful marriage to the Aegyptiads or after a second marriage as a resolution of the play. ${ }^{14}$ The second fragment (fr. 44), is said to have been spoken by Aphrodite in praise of eros, desire, which is generally assumed to belong either to the end of the play (when the girls are reconciled to marriage and - perhaps - the Thesmophoria is founded), or as part of a trial scene either of Hypermestra (for her disobedience) or of her father and sisters (for the murders). ${ }^{15}$

Nevertheless, there is another strand of the saga of Io and her descendants which had already assumed importance in the archaic period, and with this play was revived and given a new significance: the relationship of the Aegyptiads and the Danaids to the Argives, and the implications this had for the way in which relations between the Greek and non-Greek world, and Greeks and barbarians in particular, were thought about and explored in the social and political climate of the 460 s.

\section{Astoxenoi}

In scholarship on the Suppliants and the tetralogy, while the relationship between the sons of Aegyptus and daughters of Danaus frequently attracts comment, along with the flight of the maidens, their marriage, and then the murder of their cousins, another relationship that is not so often noticed is the relationship between the

to objections (cf. Garvie [n. 2], 227-8) by emphasizing the aetiological role of tragedy for marriage ritual. Likewise, F. I. Zeitlin, Playing the Other. Gender and Society in Classical Greek Legend (Chicago, 1996), 123-71, in an overtly feminist reading of the play, says that it is concerned with the institution of marriage in Argos and the slaying of husbands in response to the dismissal of women's concerns and rights, claiming that Eros and politics are inseparable and also linking the play with the Thesmophoria. Even Sommerstein (n. 2), in his rather different reading of the trilogy, concedes that (150): 'The third and arguably the dominating theme would be that of marriage.' Note also Ph. Vasunia, The Gift of the Nile. Hellenizing Egypt from Aeschylus to Alexander (Berkeley \& Los Angeles, 2001), 34-5, 47-58, who discusses the coincidence of the imagery of death, marriage and ethnicity in the Suppliants.

14 Garvie (n. 2), 228-9; Friis Johansen \& Whittle (n. 2), 41; Seaford (n. 8), 116.

15 Garvie (n. 2), 205-11, arguing against the possibility of a trial scene; Friis Johansen \& Whittle (n. 2), 1.54 . 
Aegyptiads and Danaids and the Argives. ${ }^{16}$ A recurring theme of a number of sources contemporary to the Suppliants places emphasis on the fact that Danaus became king of Argos, that Lynceus succeeded him, and that an Argive dynasty was founded from the child of Lynceus and Hypermestra. Pindar, for example, in Nemean 10 calls Argos 'the city of Danaus' (1), and says that 'in Lynceus [the city] yoked the fruit of judgement with straight justice' (13-14). Likewise, Bacchylides claimed that Zeus honours the race of Danaus and Pelasgus (11.73-9). Perhaps most importantly for the narrative content of the trilogy, Prometheus ends the account of the daughters of Danaus by proclaiming that Hypermestra, who chose to be called 'coward (analkis) rather than murderess', 'gave birth in Argos to a royal line' (Prom. 867-9). ${ }^{17}$ That Danaus succeeds to the Argive throne is probably already forecasted within the Suppliants, as at the end of the play the Argive assembly votes him a bodyguard (Aesch. Suppl. 985-8), which, as it is generally agreed, suggests that he will assume tyrannical status. ${ }^{18}$ Whether Danaus' founding of the Argive royal family through Lynceus and Hypermestra was made explicit, it was almost certainly implicit, since the action of the later part of the narrative seems to presuppose that he became king. ${ }^{19}$

The significance of Danaus' role as founder of an Argive dynasty lies in the fact that Danaus and his daughters, as well as the sons of Aegyptus, are described explicitly as stereotypically different from the Greeks, using motifs familiar from the Persians, especially the violence, luxuriousness, and exoticism of Asia. ${ }^{20}$ In fact, the continental

${ }^{16}$ Cf. P. Vidal-Naquet, 'The Place and Status of Foreigners in Athenian Tragedy', in C. B. R. Pelling (ed.), Greek Tragedy and the Historian (Oxford, 1997), 115.

17 While the precise relationship between the Prometheus and the Suppliants is unclear (not only is Aeschylus unlikely to have written both plays, and, in any case, the order in which the plays were written is impossible to recover, but also there are important differences between the plays, especially the location of the consummation of the relationship between Io and Zeus and the route of Io's journey to Egypt), nevertheless there is a self-conscious connection between the Prometheus and the Suppliants through the image of the hawks and doves (Prom. 857; Suppl. 223-4), which suggests that one play was at least aware of the other. This connection then heightens the chance that there are also elements common to both plays: see Friis Johansen \& Whittle (n. 2), 1.45-6. But note Garvie (n. 2), 227 (on the importance of the Prometheus for Aeschylus' development of the founding of the Argive royal line): ' $\ldots$ all this is pure speculation. Clearly Hypermestra's descendants are important in the Prometheus, as one of them is destined to rescue Prometheus. There is no reason why Aeschylus should necessarily have laid emphasis on them in the $\Delta$ avai $\delta \in s^{\prime}$.'

18 Garvie (n. 2), 198-202; Friis Johansen \& Whittle (n. 2), 1.50. That Danaus assumes the appearance and status of a tyrant need not be taken negatively as Hall assumes (n. 1), 156), but conveniently marks the important shift which takes place in the Argive royal line.

19 Cf. C. Calame, Poétique des Mythes dans la Grèce Antique (Paris, 2000), 130.

${ }^{20}$ For the representation of the Danaids and Aegytiads, see generally H. H. Bacon, Barbarians in Greek Tragedy (New Haven, 1961), esp. 15-30. 
polarity of Europe/Greece and Asia forms the background for the play. Io, in her wanderings, crossed from Europe to Asia (Aesch. Suppl. 544-6), and the Danaids sing of her wandering through Asia: through Phrygia, the city of Teuthras in Mysia, Lydia, the mountains of Cilicia and Pamphylia, and to Cyprus before reaching Egypt (Aesch. Suppl. 547-61). On the other hand, Pelasgus, when he introduces himself, describes his kingdom as encompassing all Greece, from Argos to the Strymon in the north-east, to the land bordering the Perrhaebians, to the parts beyond Pindus, near the Paeonians, and the Dodonian mountains, stretching towards the sea in the west (Aesch. Suppl. 254-9).

The Aegyptiads and Danaids are also described as physically different, and as having a 'dark' appearance. Although the sons of Aegyptus never themselves appear on stage (the Herald arrives to drag the maidens away, probably accompanied by attendants), ${ }^{21}$ they are said to have 'dark limbs' which show up against their white robes (Aesch. Suppl. 719-20). Even more startlingly, the Danaids are described specifically as 'non-Greek' (even unGreek) and exotic. They also refer to their dark skin and 'Nile-burned cheeks' (Aesch. Suppl. 71), and call themselves a 'sun-burned race' (Aesch. Suppl. 155). When he first meets them Pelasgus also asks:

From what country should we say this unhellenic company (anellenostolos) has come luxuriating in barbarian robes (peploi barbaroi) and wrappings? For it is not the clothing of Argive women nor even from the ways of Hellas.

(Aesch. Suppl. 234-7; cf. 120-1)

They reply: 'You have guessed the true story from our adornment' (Aesch. Suppl. 246), making it quite clear that the audience can see (or cannot fail to notice) that the women do not look Greek, but indeed look distinctly unGreek. ${ }^{22}$ Similarly, Danaus also refers to the fact that, as a result of his environment, his physiognomy is different from that of the Greeks. He asks Pelasgus for an escort on the grounds that (Aesch. Suppl. 496-7): 'In form my nature is not in keeping [with the Argives], for Nile breeds a different race from

21 Who may have formed a secondary chorus for 836-65: adopted by G. Murray in the OCT text and Friis Johansen \& Whittle (n. 2) in their edition. Note the objections of Taplin (n. 2), 217.

22 Calame (n. 19), 127-8, also makes the point that the Danaids' unGreekness is highlighted by the meeting between them and Pelasgus: 'Dès le début des Suppliantes le contraste est fortement marqué entre le caractère indigène de la lignée qui occupe Argos et l'aspect étranger de celles qui tentent d'y trouver refuge (quotation from 127).' 
Inachus.' Even more pointedly, Pelasgus, the Argive king, initially does not accept their claim to be descendants of Io, saying:

You say unbelievable things, o strangers, for me to hear,
when you say that your race is Argive,
for you are more like Libyan women
and not at like those native to our land.
And the Nile might breed such a stock,
both like the Cyprian character struck
on female form by male craftsmen,
and I hear such kind are nomads
riding with saddles on horse-like camels,
neighbours to the Ethiopian land,
and if you carried bows, I would have likened you most truly
to the manless flesh-eating Amazons.
But if you instruct me I might know more fully how your race and line are Argive.

(Aesch. Suppl. 277-90)

Here Pelasgus compares them to Libyan women, and ironically to Amazons, the women who fight men: although the Danaids are trying to escape violent men, they will in their turn inflict violence on their pursuers. $^{23}$

However, not only do they look different, but also the Danaids sound different and have different customs. ${ }^{24}$ In the opening choral song, they supplicate 'hilly Apia' (i.e. Argos), and ask it to 'pay good attention to our foreign speech (karbanos auda) (Aesch. Suppl. 117-19).' Later they are concerned that they will be badly treated because they speak a different language (allothroor) (Aesch. Suppl.

23 Depictions of Amazons in foreign dress in the imagery of the post-Persian-Wars period have generally been understood to represent the conflict between 'Greeks and others', especially the conflict between Greeks and Persians, in which the Persians have become 'feminised'; e.g., E. Hall, 'Asia Unmanned: Images of Victory in Classical Athens', in J. Rich \& G. Shipley (edd.), War and Society in the Greek World (London \& New York, 1993), esp. 114-15. See now, however, R. Veness, 'Investing the Barbarian? The Dress of Amazons in Athenian Art', in L. Llewellyn-Jones (ed.), Women's Dress in the Ancient Greek World (London \& Swansea, 2002), 95-110, who argues that while Amazons are depicted in barbarian/Persian dress, they are also shown in Greek dress, and represent a complex and shifting exploration of the dangers of women, and especially those women who have been brought as wives into the household. As a consequence, Amazons in Persian dress do not explain the conflict between Greeks and Persians, but between men and women. She writes (106): 'This is the effect of the artistic amazonomachies, with their evenly-matched battles poised on the point of danger, with their clothing of Amazons in Greek dress, foreign dress, masculine dress, and feminine dress, characterizing women as both insider and outsider, the hidden heart of destruction from within... The real danger is from the woman who has been integrated, taken into the household. You must marry the Amazon, the woman, but she remains an Amazon, remains a danger.' On this reading the comparison between Amazons and Danaids is even more appropriate: brides who murder husbands.

24 Bacon (n. 20), 15-16; E. Hall (n. 1), 128, 136, 139. 
972-3). Also, like Atossa in the Persians, they cannot comprehend a political system in which the people hold the final decision-making powers (Aesch. Suppl. 370-5).

The Aegyptiads, for their part, are also violent, and their violence is one of the principal reasons the Danaids give for their flight from the hateful marriage. They describe their cousins as a 'male-thronged, violent (hubristes), Aegyptus-born swarm' (Aesch. Suppl. 29-30), and pray that they may be saved by gods who respect justice and hate violence (Aesch. Suppl. 78-82; cf. 104-5, 426-7). The violence of the Aegyptiads is borne out by the Herald's behaviour in the final scenes of the play, when he threatens to drag the maidens forcibly from the altar. In the lyrics, he (or perhaps his Egyptian henchmen) tells them to get on the ship or they will be pricked and poked, and, murderously and with much gore, have their heads cut off (Aesch. Suppl. 836-41), and threatens to drag them away by the hair (Aesch. Suppl. 884, 909) and to tear their clothes (Aesch. Suppl. 903-4). ${ }^{25}$

In appearance at least, Danaus and his daughters are outsiders, and so are fearful of their status in the city. This takes two forms. Firstly, although they are confident about their right to be suppliants on the basis of their kinship, they are concerned about the reception of their supplication and their status as xeinai, foreigners, and suppliants. When they first arrive in Argos and see the king and his army approaching, Danaus exhorts his daughters to perform the ritual abasement in the awareness that they are foreigners:

Go as quickly as possible, and,

holding reverently in your left hand

the white-wreathed suppliant branches,

the trophy of reverend Zeus,

answer the strangers (xenoi),

in words full of reverence, mournful, and needy,

as is seemly for foreigners (epéludes),

telling plainly of your flight, unstained with blood, ${ }^{26}$

accompany your voice first of all with a lack of boldness,

and let no frivolity proceed from a modest-browed face and quiet eye.

In your speech, do not be forward or lagging. This is a very grudging race.

And remember to give way; you are in need, a stranger $(x e n \bar{e})$, a fugitive.

Boldness of speech is not seemly for those who are weak.

(Aesch. Suppl. 191-203)

25 Although Taplin (n. 2), 216, makes the point that he only threatens physical force, and there is no indication that he actually uses it.

${ }^{26}$ Note the irony here (as at 6), since they may be unpolluted by murder before their flight, but they will murder the Aegyptiads and cause pollution. 
Danaus is concerned that their supplication will be accepted, and to an extent his concern is justified. Pelasgus identifies the tension between the interests of foreigners and the interests of the state, and because of the possibilities of war will not act without the consent of the people: 'I would not do these things without the demos ... in case one day someone should say, if somehow something untoward happened, "in honouring foreigners (epeeludes) you have destroyed the city"' (Aesch. Suppl. 398-401). In this sense, the play is concerned with supplication, as the title of the play suggests. ${ }^{27}$

More importantly for our purposes, the Danaids are also concerned that their reception within the city might be problematic on the grounds that they are obviously (and even ethnically) different from the Greeks. Danaus, when requesting the escort, says that it is necessary for them to be on their guard, since 'confidence gives birth to fear; indeed before now a man has killed a philos ('friend'/'kinsmen') out of ignorance' (Aesch. Suppl. 498-9). Likewise, the Danaids themselves ask that their father be sent on ahead to arrange their accommodation, since 'everyone is ready to cast reproach on those who speak a different language (allothrool)' (Aesch. Suppl. 972-3). Danaus himself confirms the general lack of respect for outsiders when he says: 'In regard to an unknown company, as is proved in time, everyone readily bears an evil tongue, and to utter slander is quite easy' (Aesch. Suppl. 993-5), and follows with warnings about the temptation for men of virginal loveliness and advises them to honour their modesty more than their life, possibly an ironic reference back to the 'Cyprian character' of their faces. The Aegyptiads and Danaids are foreigners, outsiders, and are explicitly described as unHellenic: they have dark skin, wear exotic clothing, speak a different language (or at least are represented as sounding different). The men at least are violent, and the women are inherently suspicious because of their 'otherness'.

Nevertheless, despite appearances, the Danaids are also insiders who have a positive right to supplicate the Argives because they are descendants of Io (Aesch. Suppl. 16-19, 274-6, 291-324). Pelasgus, after hearing the whole story of their descent, believes their story and accepts their ancient claims of kinship (Aesch. Suppl. 325-6), as do the Argives (cf. Aesch. Suppl. 632, 652). Furthermore, they are acceptable as insiders since they have 'Hellenic' aspects: in particular, they are modest, and, unlike the Egyptian herald, honour Greek gods,

${ }^{27}$ Friis Johansen \& Whittle (n. 2), 1.37. 
and call on Zeus, Apollo, Poseidon and Hermes 'in his Hellenic form' (Aesch. Suppl. 210-23).

In short, the daughters of Danaus are both insiders and outsiders, and Pelasgus sums up the ambiguity of their position when he calls them astoxeinoi, citizen-strangers. ${ }^{28} \mathrm{He}$ says, with a certain amount of regret at the relationship:

I see shaded with new plucked branches this whole company of presiding gods nodding.

But may this affair of astoxenoi be harmless, and may there not be trouble for the city unexpected and unprepared. For the city does not need these things.

(Aesch. Suppl. 354-8)

The primary meaning of xenos is 'outsider', who is only given a place inside society because of the intervention of Zeus Xenios and Hikesios. ${ }^{29}$ In a similar way, suppliants can be outsiders who are drawn into the community. ${ }^{30}$ Rejection of their rights as suppliants would be a cause of pollution (cf. Aesch. Suppl. 359-86, 428-32). ${ }^{31}$ Thus the Danaids call on Zeus Hikesios to accept and represent their supplication (Aesch. Suppl. 26-7, 347, 385-6, 641; cf. 190-2, 478-9, 616), and when their supplication has been accepted celebrate Zeus Xenios (Aesch. Suppl. 670-3). Nevertheless, despite their status as outsiders, they are kin and so members of the community. Danaus makes the point explicitly about their dual claim when he reports back that Pelasgus, in the assembly, told the Argives that to reject the Danaids' claims would give rise to a two-fold pollution both of stranger (xenikon) and citizen (astikon) (Aesch. Suppl. 618-20). ${ }^{32}$

Like the Erinyes of the Eumenides at Athens (Aesch. Eum. 1011, 1018), the Danaids are received into the city of Argos as metoikoi

28 Cf. Vasunia (n. 13), 40-3. Pindar also uses astos and xenos as opposites: Ol. 13.1-3: 'In praising a house thrice victorious at the Olympic games, gentle to asto $i$ and playing host to xeno $i$ ...'; Pyth. 4.73-9 (Pelias wanted to be on his guard against the one-sandled man, whether xeinos or astos.)

29 L. G. Mitchell, Greeks Bearing Gifts. The Public Use of Private Relationships, 435-323 BC (Cambridge, 1997), 16-17.

30 Supplication followed two basic patterns: 'help me' and 'spare me' supplication; see J. Gould, 'Hiketeia', fHS 93 (1973), 74-103; R. C. T. Parker, Miasma (Oxford, 1983), 181-5. Parker notes (181) that 'the "help me" suppliant (literally 'comer') is clearly assimilated to the to the stranger... Such a suppliant had an absolute claim not to be harmed by the person he had supplicated; this claim, guaranteed by Zeus of Suppliants, was an intensification of the stranger's similar claim, guaranteed by Zeus of strangers.'

31 Parker (n. 30), 146.

32 Cf. Friis Johansen \& Whittle (n. 2), 2.285 at 356 on astoxenos. 
(Aesch. Suppl. 609, 994), ${ }^{33}$ and are given housing within the city (Aesch. Suppl. 957-61, 1009-11). On one level then the trilogy may well be concerned with providing an aetiology for the Thesmophoria. However, more profoundly, the acceptance of the Danaids and their supplication, and especially their kinship, is an acceptance of their right to belong. Foreign as they are, as much as they look like outsiders, they are insiders.

The dual role of the Danaids as insiders and outsiders seems to be fundamental to the play, and probably was for the trilogy also. Non-Greekness, and a non-Greekness which is described in 'barbarian' terms (although, astoundingly, the word barbaros is used only once in the play, and then to describe the Danaids' clothing (Aesch. Suppl. 235); otherwise they are epéludes, 'incomers, strangers'), is brought right to the heart of Greekness. Not only are the Danaids accepted as kin of the Argives, but also it is implicit in their story that from the marriage of Hypermestra and Lynceus the Argive royal line will be founded. The Danaids are dark skinned and exotic, yet they are also homaimos, of the same blood, as the Argives.

Nevertheless, the inclusion of the Danaids within the community of the Argives is not uncomplicated. The relationship between the Aegyptiads and the Danaids is a significant relationship in the play, and they have an aversion to marriage with 'self-same kin' (autogenei phyxanoriai) (Aesch. Suppl. 8). But if the Danaids are kin to the Argives, then so are their violent cousins, the Aegyptiads, whose absolute 'non-Greekness' is accentuated by the Herald's refusal to acknowledge Greek gods: 'I do not fear these gods. They did not rear me or bring me to full age by their care' (Aesch. Suppl. 893-4; cf. 921-3). In addition, the Danaids, whatever the reason for their flight (whether provoked by fear, either of marriage in general, or marriage in particular with their cousins), are not wholly innocent in their supplication. ${ }^{34}$ Not only do they threaten Pelasgus with their suicide (and consequent pollution) if he does not win their right to be received as suppliants (and equally struggle to accept that he is unable to make this decision without the Argive people: Aesch. Suppl. 354-80), but also they threaten the gods if they do not lend their assistance:

\footnotetext{
33 On the parallel with Eumenides: I owe this point, with thanks, to Professor Richard Seaford; cf. F. I. Zeitlin, 'Thebes: Theatre of Self and Society in Athenian Drama', in J. J. Winkler \& F. I. Zeitlin (edd.), Nothing to Do With Dionysos? Athenian Drama in its Social Context (Princeton, 1989), 145. On the Danaids' status as metoikoi: Garvie (n. 2), 182; Friis Johansen \& Whittle (n. 2), 1.44.

${ }^{34}$ Friis Johansen \& Whittle (n. 2), 1.37-8.
} 
If not, we a black

sun-burnt race

will offer supplication to the earth,

which is most hospitable,

to Zeus of the dead

with our branches,

dead by the noose,

if we do not get satisfaction from the Olympian gods.

(Aesch. Suppl. 154-61)

The Danaids, like their cousins, are not straightforward. The physical differences between the Danaids and the Argives, it is suggested, are environmentally conditioned. They are 'Nile-bred' and 'sun-blackened'. Nevertheless, while the Danaids' appearance may suggest a non-Greek origin or at least backgound, the Danaids are 'of one blood' both with the Aegyptiads and with the Argives. Even more, however, the union of a Danaid and an Aegyptiad is to found an Argive royal house. As we have already seen, the removal of the 'Pelasgian' house, and its replacement by 'barbarians', is already prefigured within the Suppliants. Consequently, the issues raised by this play are profound. In the context of this play, a simple categorization of 'Greeks and barbarians' or 'self and other' is not adequate. ${ }^{35}$

\section{Greeks and barbarians at the Great Dionysia}

This is an Athenian play aimed in the first instance at an Athenian audience. ${ }^{36}$ The action of the play is set in Argos, which Zeitlin has argued acts in general terms as the middle ground between Athens and the anti-Athens, Thebes. While Thebes becomes a closed and confined mythic space in which the Athenian audience can watch

\footnotetext{
35 Similarly, the formulation 'other in self', on which see S. Greenblatt, Marvellous Possessions (Oxford, 1991), 127, which has been applied to Herodotus and which Pelling has found useful in his discussion of the Persians, also does not do justice to the complexity of the exploration of the Greek relation with non-Greek in the Suppliants, or, perhaps, more precisely, the Athenian exploration of this question. For Pelling on 'other in self' in Aeschylus' Persians: 'Aeschylus' Persae and history', in C. B. R. Pelling (ed.) (n. 16), 19.

36 Although there is an increasing awareness that plays produced at Athens may also have been staged elsewhere, or that they may have had and been intended to have resonance for non-Athenian elements in the audience at the Dionysia: O. Taplin, Comic Angels, and Other Approaches to Greek Drama through Vase-painting (Oxford, 1993); P. Easterling, 'Euripides Outside Athens: a Speculative Note', ICS 19 (1994), 73-80; O. Taplin, 'Spreading the Word through Performance', in S. Goldhill \& R. Osborne (edd.), Performance Culture and Athenian Democracy (Cambridge, 1999), 33-57; cf. P. J. Rhodes, 'Nothing to Do with Democracy: Athenian Drama and the Polis', fHS 123 (2003), 104-19.
} 
re-enacted 'these same intricate and inextricable conflicts that can never be resolved and which are potentially present for the city of Athens', Argos is the city of redemption, and provides possibilities denied by Thebes. ${ }^{37}$

The Argos of the Suppliants is Athens' alter-ego. It is ruled by Pelasgus, 'a model king, just like Theseus, and a democratic city that closely resembles the Athenian ideal.' ${ }^{38}$ It, like Athens (and Thebes), boasts origins as autochthones. Aeschylus - and here he is being original - makes Pelasgus the son of a gegenēs ('earth-born'), Palaecthon, 'Ancient Earth', although Acusilaus before him had already made Pelasgus Argive (FGrHist 2 F25).$^{39}$ Herodotus writing in the late fifth century says that the Athenians were Pelasgian (Hdt. 1.56.2, 8.144.2), although he also tells other stories in which the Athenians expel the Pelasgians from Attica (Hdt. 6.136-40). The Athenian audience is also helped to identify with the daughters of Danaus by their singing of 'Ionian songs' (Iaonioi nomo $)$ (69), surely at least a double pun, alluding also to the Danaids' descent from Io (the Argives in the fifth century claimed Dorian antecedents).

But here lies an irony which turns on the traditions about the Pelasgians. Pelasgians were considered 'barbarian' in the sense that they were non-Greek, and Herodotus makes much of the fact that the Athenians, through their Pelasgian origins, were barbarians who became Greek (Hdt. 1.56.2-57.3), and, whatever the agenda of his own work, surely he could not be referring innocently to barbarians without an awareness of its popular and pejorative overtones. ${ }^{40}$ It is ironic then that Pelasgus, the son of the Earth-born, should be the agent, even if indirectly, for the (re)founding of the new non-Greek, 'barbarian' (in act and appearance, if not in name), dynasty in Argos.

How then should the play (and the tetralogy) be contextualized and interpreted? For Calame the trilogy, by the 'refounding' of Argos through the union of Lynceus and Hypermestra, reworks for the Athenians their autochthony, providing within the context of the ideological rhetoric of 'Greeks and barbarians' a new model for the place of Athens within a consciously united Greece in the

37 Zeitlin (n. 33), esp. 145-6.

38 Zeitlin (n. 33), 145.

39 Other traditions claim that the king in Argos when Danaus arrived was Gelanor or Helanor: Paus. 2.16.1, 19.3 (Danaus and Gelanor quarrelling over the Argive throne); schol. Il. 1.42 .

40 R. Thomas, 'Ethnicity, Genealogy and Hellenism in Herodotus', in I. Malkin (ed.), Ancient Perceptions of Greek Ethnicity (Washington, 2001), 224-5, here suggests that Herodotus is taking a deliberate and provocative swipe at the Athenians. 
post-Persian-Wars world. ${ }^{41}$ It might also be argued within a ritual and civic context that the play is concerned with the incorporation of 'the Other' within civic and ritualized structures of the Athenian polis. ${ }^{42}$

The play can also be read against political and historical contexts, where the play illuminates the historical narrative and the historical narrative illuminates the play. On this level, the Suppliants seems to represent the opening up of Athenian attitudes to the non-Greek world, or at least to Egypt. Only a few years later, the Athenians were involved (ultimately disastrously) in the Egyptian revolt from Persia, which was set in motion by the Libyan Inaros (Thuc. 1.104). Although the Athenians undoubtedly had mixed motives for the war, as it could be seen both as the continuation of the war against Persia and as an opportunity to explore new markets for grain, ${ }^{43}$ the campaign may have been made more acceptable by a mood of renewed interest in the 'kinship' of the Egyptians. We may then be seeing the Athenians, after taking on board and incorporating the Greek-barbarian polarity within their ideological framework, making distinctions between different kinds of barbarians. Nevertheless, in the play the Aegyptiads are straightforwardly, stereotypically and negatively 'barbarian' (although they are never given that name), and even the Danaids are not represented in a wholly positive light and by no means represent a 'Greek face' of barbarity.

We should, moreover, be hesitant in making too simple a connection between Athenian interest in Egypt and representations of Egyptians. Margaret Miller has shown in her analysis of the Busiris myth in Athenian vase-painting that Busiris and his court, who in earlier vase-painting were identifiably Egyptian because of their stereotypical appearance, from the 460s become 'persianised' by being depicted in Persian clothing, ${ }^{44}$ as were other non-Greek mythical figures who previously had been represented with distinctive and racially stereotyped characteristics. Miller suggests that the creation of

${ }^{41}$ Calame (n. 19), 130-4.

42 Note especially Vidal-Naquet (n. 16).

43 The possibility that the Athenians were actively seeking a new supply of grain from Egypt is supported by the vast amount of grain given to the Athenians as a gift by the Egyptian Psammetichus (Philochorus, FGrHist 328 F 119): R. Meiggs, The Athenian Empire (Oxford, 1972), 95, 268; S. Hornblower, The Greek World 479-3233 (London, 2002), 31-2. However, for doubts about the Athenians' need for such grain supplies on a regular basis before Peloponnesian War: P. Garnsey, Famine and Food Supply in the Graeco-Roman World. Responses to Risk and Crisis (Cambridge, 1988), 89-133; J. R. Sallares, The Ecology of the Ancient Greek World (London, 1991), 97-8.

${ }^{44}$ M. C. Miller, 'The Myth of Bousiris: Ethnicity and Art', in B. Cohen (ed.), Not the Classical Ideal. Athens and the Construction of the Other in Greek Art (Leiden, 2000), 430-2. 
a generic Other, where 'all foreign others were forced into the straitjacket of the great "Other", resulted from 'shifts in dominant ideology as a result of both democracy and empire. It was a striking rejection of the thoroughgoing internationalism of the Archaic aristocratic mindset and revealed the exclusivity of the Classical democracy whose imperial activities necessarily comprehended an international forum even while its domestic politics permitted little internal overt class distinction. ${ }^{45}$

Furthermore, from the 460s or a little later, Greek (and Athenian) relations with the East, not just Egypt but Persia as well, had started to open up again. By the time the Suppliants was written in the late 460 s, the political climate had altered from that of 472 when the Persians was produced. Cimon was exiled in 461 (Plut. Cim. 17.2), suggesting that he and his anti-Persian policies were not looked upon as favourably as they had once been, ${ }^{46}$ though he later returned to Athens and undertook a final and not inglorious campaign to Cyprus in the late $450 \mathrm{~s}$ (though it ended with his death) (Thuc. 1.112.2-4; Plut. Cim. 18.1-19.1). Meanwhile, in 454 the war in Egypt had ended badly with heavy losses for the Athenians and their allies (Thuc. 1.110.4). Even before this, Argive and Athenian ambassadors had been found at the Persian court. Sometime after the death of Xerxes and accession of his son in 465, Herodotus says that Argive ambassadors went to Persia to test their relationship with the new king, renewing their friendship (philia) with him (Hdt. 7.151). ${ }^{47}$ Intriguingly, he adds the detail that Athenian ambassadors were also there at the time, including Callias son of Hipponicus, 'on another matter', although he never explains what their business at Susa may have been.

\footnotetext{
45 Miller (n. 44), 441.

${ }^{46}$ Although the more immediate cause of his exile must have been the Athenians' involvement at Ithome.

47 The date of this conference in Susa is unclear. As R. Osborne notes, The Athenian Empire 4 (LACTOR 1) (London, 2000), 31, it could have been any time between Artaxerxes' succession in $465 / 4$ and his death in 424 , although most prefer a date of just after 465 or in the 450 s as part of the negotiations for the Peace of Callias. For a date in 465: J. Walsh, 'The Peace of Callias and the Congress Decree', Chiron 11 (1981), 31-63; K. Meister, Die Ungeschichtlichkeit des Kalliasfriedens und deren historische Folgen (Palingesia 18) (Wiesbaden, 1982), 22-4; for a date in 464: E. Badian, 'The Peace of Callias', FHS 107 (1987), 2-3 = From Plataea to Potidaea (Baltimore, 1993), 3-4; for a date in the 450s: D. M. Lewis, Cambridge Ancient History V ${ }^{2}$ (Cambridge, 1992), $122 \mathrm{n}$. 4. It is not necessary to conclude, however, even if these negotiations did take place in the 460 s, that they were not preliminary negotiations that resulted in the Peace of Callias. Both Spartan and Athenian ambassadors were travelling back and forth to the Spartan court at least from the 430s, although for Sparta at least the talks were not productive until 412. The Athenians, although they seem from the 430s to have been angling for financial support - Thuc. 2.7.1; Aristoph. Acharn. 106-9; pace K. J. Dover, Aristophanic Comedy (Berkeley \& Los Angeles, 1972), 78 n. 1; J. J. Price, Thucydides and Internal War (Cambridge, 2001) 364-6 - at least managed to conclude the Peace of Epilycus, probably in the 420 s.
} 
While the Argives had, during the conflict with Persia, maintained at least a neutral position and had declined to take part in the Greek resistance (on the grounds both that an oracle advised against it and that the Spartans had rejected the Argive claim to joint leadership, to which according to Herodotus the Argives replied that they would rather be ruled by the barbarians than by the Spartans: Hdt. 7.149.3), the Athenian presence is surprising. It is possible, as some have supposed, that Callias and his colleagues were involved in early negotiations for the Peace of Callias, ${ }^{48}$ but in any case the war with Persia had apparently started moving into a new phase, and other diplomatic possibilities were being explored. ${ }^{49}$

Nevertheless, it is certainly true that by the second half of the fifth century the barbarian as the natural enemy was rhetorically and ideologically entrenched, and that this motif persisted through later centuries. The image of the luxury-loving and violent barbarians who were also proficient with drugs and magic was developed through fifth- and fourth-century literature. Aristophanes has great fun with Athenian ambassadors 'dying' of luxurious living at the Persian court (Acharn. 61-90). In the Iphigeneia at Aulis, Paris comes to Sparta 'flower-bright in raiment, and shining with gold, barbarian luxury' (73-4). Likewise, recalling Circe (among others), ${ }^{50}$ Euripides' Andromache is accused (though falsely) of making Hermione childless and hateful to her husband with drugs (Androm. 32-3), and Medea kills Glauce with a poisoned wedding gown (Med. 1156-202). In the Helen Theoclymenus the Egyptian king threatens to kill all Greeks that come to Egypt (155, 468, 778, 1173-6), while among Iphigeneia's Taurians the sacrifice of Greeks to Taurian Artemis is described with blood-dripping detail (IT 72-6). Likewise, Xenophon in the fourth century borrows from the stereotypical contrast between simple Greek and luxury-loving Persian to heighten the dramatic tension in his description of the meeting between Agesilaus and the

${ }^{48}$ Although this need not necessarily be indicated by Callias' presence at Susa since the role of ambassador to the Persian court seems to have been held by his family; but it is impossible to tell when this connection was first made.

49 M. C. Miller, Athens and Persia in the Fifth Century BC. A Study in Cultural Receptivity (Cambridge, 1997), 16, notes that this embassy (if it does date to the mid 460s) did not stop Pericles and Ephialtes sailing beyond the Chelidonian islands (Callisthenes, FGrHist $124 \mathrm{~F} 16=$ Plut. Cim. 13.4). However D. M. Lewis, Sparta and Persia (Cincinnati Classical Studies ${ }^{2}$ 1) (Leiden, 1977), 60 n. 68, finds it 'impossible to believe that Pericles was general in the 460s.' See also H. T. Wade-Gery, Essays in Greek History (Oxford, 1958), 203 n. 1. Meiggs (n. 43), 79 n. 1, on the other hand, argues for the date in the 460s.

50 Note also that Helen procures drugs from an Egyptian woman: Homer, Od. 4.220-32. 
Persian satrap Pharnabazus at Dascyleium in 395 (Xen. Hell. 4.1.29-39).

Yet, alongside this ideology of difference there were now also new ways (or a reinvigoration of older ways) of thinking about the barbarian. Xenophon, who marched an army through Asia (where he served one barbarian, was betrayed by others, and met barbarians who were hostile as well as those who sought the friendship of the Greeks), is aware of difference (even 'Herodotean' extremes of difference: Xen. Anab. 5.4.30-4), and is as willing to see the barbarians as friends as he is to fight them as enemies. Likewise, just as Euripides exploits the idea of a Greek/barbarian polarity in his delineation of character, he also undercuts it. ${ }^{51}$

The late 460s presented itself then as a time to reinvestigate relationships with a wider world in a sharp and incisive way. That the Greek-barbarian polarity now formed part of the vocabulary of Greek/non-Greek relationships is clear from the Suppliants. But the polarity itself did not necessarily, or not always, inform the perceptions of the relationship between the Greek and non-Greek worlds, or indeed the diplomatic and practical realities of that relationship. The discourse which sought to locate the Greeks in a 'whole world space' was investigated in greater depth and with greater sharpness. If Greek and barbarian were united by kinship (as the Danaids claim), and, more strikingly, if Greek was barbarian (through Hypermestra and Lynceus) and barbarian Greek (through Io), then questions were not only being aired about the polarity and its characterizing stereotypes, but also about the nature of Greekness itself and its relationship with the non-Greek world. By relocating the Hellenes in the wider world, and making Greekness non-Greek and non-Greekness Greek, the polarity was subverted. The analogue between Greek/barbarian, civilized/uncivilized, though often assumed to be in place until the late fifth century (yet already challenged in the Persians), was broken, allowing room and creating an 'ideological space' for the questions about the nature of barbarism and even different kinds of barbarism to develop in new directions, and also for new political attitudes to the Persian and in particular to Persian money. 